logos_i_ethos_2021_1_(56), s. 7-28

DOI: http://dx.doi.org/10.15633/lie.3936

Wojciech Kleofas Gródek OFM

https://orcid.org/0000-0002-5006-5537

Uniwersytet Papieski Jana Pawła II w Krakowie

\title{
Przyjemność i dobro w dialogu Protagoras Platona
}

Czy przyjemność jest związana z doświadczeniem dobra? Sugestia o takim powiązaniu pojawia się w dialogu Protagoras Platona, gdy Sokrates wygłasza tezę: „więc może przyjemnie żyć to dobrze" ${ }^{1}$.

Wojciech Kleofas Gródek OFM, doktor, wykładowca historii filozofii starożytnej i średniowiecznej na Wydziale Filozoficznym UPJPII w Krakowie. Członek zarządu Towarzystwa Metafizycznego im. A. N. Whiteheada. Zajmuje się wczesną filozofią grecką, w szczególności szkołą eleacką. Czy jednak w części dialogu poruszającej wyrażony w cytowanym zdaniu pogląd Platon ustami Sokratesa rzeczywiście chce wykazać związek przyjemności z dobrem i czy można doszukać się również informacji o dobru? Wątpliwości co do pozytywnej odpowiedzi na to pytanie pojawiają się w kontekście opinii komentatorów na temat stosunku Platona do samego hedonizmu. Artur Pacewicz stwierdza, że „pogląd na przyjemność reprezentowany w dialogu Protagoras już od dawna sprawiał badaczom kłopoty interpretacyjne"2 . Powołuje się przy tym na opinię Reginalda Hackfortha, według którego przedstawiona w tym dialogu przez Sokratesa hedonistyczna teoria etyczna jest sprzeczna z poglądami przypisywanymi mu w innych dialogach oraz z ogólną znaną wizją człowieka reprezentowaną przez samego Platona ${ }^{3}$. Jeżeli Hackforth ma rację, to dlaczego w tym dialogu Platon ustami

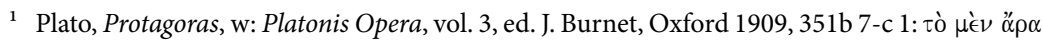

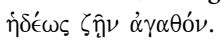

2 A. Pacewicz, Hedone. Koncepcja przyjemności w filozofii Platona, Wrocław 2016, s. 172.

3 Zob. R. Hackforth, Hedonism in Plato's Protagoras, „Classical Quarterly” 22 (1928), s. 40. 
Sokratesa usilnie zabiega o akceptację związku przyjemności z dobrem? John P. Sullivan, zwraca uwagę na trzy możliwe sposoby wyjaśnienia postawy Sokratesa zaprezentowanej przez Platona. Część interpretatorów prezentuje opinię, że jest to prawdziwe spojrzenie samego Sokratesa lub wczesnego Platona z czasu, kiedy pisał dialog. Natomiast inna grupa komentatorów sugeruje, że przesłanka, iż jedynie dobro jest przyjemnością, została użyta przez Sokratesa do udowodnienia tezy, że cnota jest wiedzą. Nie jest to równoznaczne $\mathrm{z}$ wiarą Sokratesa w treść przesłanki. Sullivan dostrzega również obecność trzeciego poglądu, według którego w tym dialogu nie występuje żaden prawdziwy hedonizm ${ }^{4}$. W tym przypadku powołuje się na stanowisko prezentowane przez Thomasa D. Goodella, który twierdzi, że Platon nigdy nie popierał hedonizmu. Jedynie pobieżne czytanie tekstu Protagorasa, w którym znajduje się tylko pewna aluzja, mogłoby skłonić do uznania, że Platon ustami Sokratesa popiera hedonizm ${ }^{5}$. Mając na uwadze rozbieżność poglądów na ten temat, Donald J. Zeyl stawia dwa pytania. Po pierwsze, jeżeli w Protagorasie Sokrates poważnie traktuje hedonizm, to jak to się ma do jego ataków skierowanych w tę stronę w dialogu Gorgiasz? Po drugie, jeżeli jednak nie przedstawia siebie poważnie jako hedonistę, to dlaczego swoim rozmówcom pozwala postrzegać siebie jako wierzącego w przyjęte

4 Zob. J. P. Sullivan, The Hedonism in Plato's „Protagoras”, „Phronesis” 6 (1961) No. 1, s. 10. Artur Pacewicz w swojej monografii, klasyfikując poglądy próbujące uporać się z problemem nakreślonym przez Hackfortha, pisze: „W tradycyjnym, ewolucyjno-rozwojowym paradygmacie interpretacyjnym można by problem ten rozwiązać na przykład poprzez przypisanie tego poglądu Platonowi, a nie historycznemu Sokratesowi, co jednak, ze względu na trudności implikowane przez tak zwaną «kwestię sokratejską», wydaje się trudne do uzasadnienia. Można również uznać, że stanowisko hedonistyczne zostaje zaakceptowane po to, aby - patrząc z sofistycznego punktu widzenia - obalić poglądy sofistyczne albo pokazać sofistom, iż ich poglądy nie są w żaden sposób wyjątkowe, lecz wyrażają zdroworozsądkowe stanowisko, zgodnie z którym to, co dobre, utożsamione zostaje z tym, co przyjemne. Możliwe ponadto jest uznanie argumentacji zawartej w dialogu, w tym oczywiście tej prowadzonej na rzecz hedonizmu, za ambiwalentną filozoficznie, za mającą charakter erystyczny (ad hominem), za ironiczną lub w ogóle odrzucaną przez Platona" (A. Pacewicz, Hedone. Koncepcja przyjemności w filozofii Platona, dz. cyt., s. 173).

5 Zob. T. D. Goodell, Plato's Hedonism, „The American Journal of Philology” 42 (1921) No. 1, s. 25 . 
na początku założenie, że przyjemne życie jest dobre? ${ }^{6}$ Próbą uporania się z przedstawionymi trudnościami może być opinia, którą zaproponował Charles H. Kahn, pisząc, że „Sokrates nigdzie nie akceptuje utożsamiania dobra z przyjemnością (...) wyraził jedynie słabszy pogląd, że przyjemność jako taka jest czyś dobrym i że bycie przyjemnym jest pod tym względem - jako bycie przyjemnym - byciem dobrym"7 . Z tego też powodu uznaje, że w dialogu Protagoras jest przedstawiony jedynie schematyczny model wiedzy o dobru, oparty na utożsamianiu dobra z przyjemnością. Tak więc stwierdzenie, że przyjemność jest dobrem, nie byłoby oparte na znajomości dobra. Jedyne uzasadnienie dla przyjęcia takiej tezy mogłoby wynikać z faktu, że przyjemność jest obiektem powszechnego pragnienia i dążenia ${ }^{8}$. Trzeba więc zastanowić się nad tym, co decyduje o tym, że odczucie przyjemności jest uznawane za dobro? Odpowiedź na to pytanie wymaga najpierw zastanowienia się nad powodem skupienia się przez Platona w tym dialogu właśnie na przyjemności. Następnie należy podjąć próbę rozpoznania cech wskazujących na doświadczanie dobra. Jeżeli więc powszechnie pragnie się i dąży do przyjemności, to również należy zastanowić się nad warunkami skutecznego osiągnięcia tego celu.

\section{Próba rozpoznania celu dyskusji o przyjemności}

Sokrates, dyskutując z Protagorasem, stawia tezę: „o ile coś jest przyjemne, czy nie jest dobre, pytając o przyjemność samą, czy ona nie jest

6 Zob. D. J. Zeyl, Socrates and Hedonism: „Protagoras” 351b-358d, „Phronesis” 25 (1980) No. 3, s. 250 .

7 Ch. H. Kahn, Platon i dialog sokratyczny, tłum. M. Filipczuk, Warszawa 2018, s. 392.

8 Zob. Ch. H. Kahn, Platon i dialog sokratyczny, dz. cyt., s. 412. To uzasadnienie dla zestawiana przyjemności z dobrem jest oparte na sposobie myślenia Platona o dobru, przedstawionym w dialogu

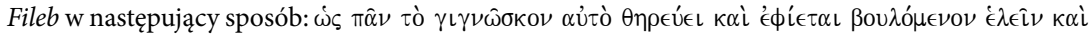

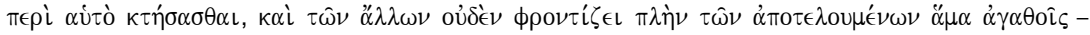
„że każdy, kto poznaje, ściga je [dobro] i pragnie, chce chwycić i dla siebie zdobyć, i z innych [rzeczy] nic nie kontempluje oprócz tych dokonanych równocześnie z dobrami” (Plato, Philebus, w: Platonis Opera, vol. 2, ed. J. Burnet, Oxford 1910, 20d 5-7). 
dobrem"9. Według Artura Pacewicza ${ }^{10}$ jest ona zmodyfikowaną wersją wcześniejszej wypowiedzi Sokratesa: „według czego coś jest przyjemne, czy według tego nie jest dobre, jeśli z nich nic innego nie wynika?" ${ }^{11}$. Wydaje się jednak, że zdanie 351e 2-3 zawiera w sobie dość istotne dopowiedzenie. Zdanie 351c 4-5, rozpoczyna się od $\kappa \alpha \theta$ ' ö, czyli „według czego", które mogłoby być odwołaniem się do czegoś, co powoduje, że rzeczy lub

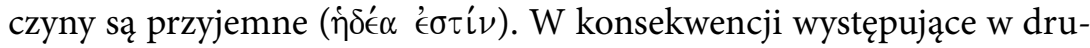

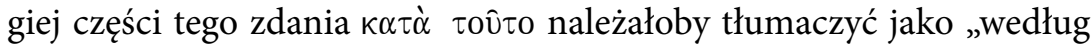

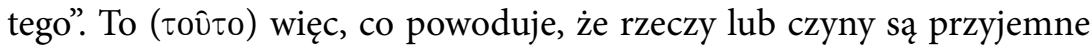
$\left(\dot{\eta} \delta \delta^{\prime} \alpha\right)$, ukazuje je jako dobre $(\dot{\alpha} \gamma \alpha \theta \dot{\alpha})$. Dodane do tego wnioskowania dopowiedzenie, że nie jest takie, jeżeli coś innego ( $\tau \iota \ddot{\alpha} \lambda \lambda \mathrm{\lambda}$ ) z tych rzeczy

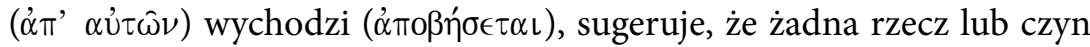
nie są trwale przyjemne $\left(\dot{\eta} \delta \delta^{\prime} \alpha\right)$. Jeżeli więc dana rzecz lub czyn straci taki charakter, przestają być określane jako przyjemne (j门ó́), a w konsekwencji i dobre (’’ $\gamma \alpha \theta o ́ \nu)$. Można przypuszczać, że w zdaniu tym Sokrates koncentruje się nie na jakiejś rzeczy lub czynie, ale na tym, czy spełnia warunki właściwe przyjemności czy też nie ${ }^{12}$. Wydaje się więc, że w tym kontekście interpretacyjnym zdanie 351e 2-3 może być rozumiane jako dopowiedzenie wskazujące na faktyczny sens zdania 351c 4-5. Sokrates rozpoczyna zdanie 351e 2-3 od $\kappa \alpha \theta$ ' ő $\sigma o \nu$, czyli „o ile”. Jest to kontynuacja

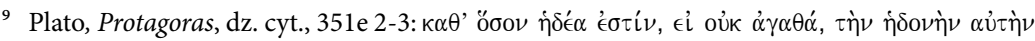

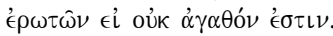

10 Zob. A. Pacewicz, Hedone. Koncepcja przyjemności w filozofii Platona, dz. cyt., s. 179.

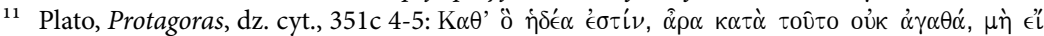

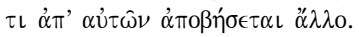

12 Sens tego zdania jest rozumiany przez komentatorów różnorako. Donald J. Zeyl parafrazuje to zdanie w następujący sposób: „przyjemne rzeczy są dobre w szacunku (pod względem), w którym / do stopnia, do którego one są przyjemne" (pleasant things are good in the respect in which / to the extent to which they are pleasant) (D. J. Zeyl, Socrates and Hedonism: „Protagoras” 351b-358d, dz. cyt., s. 251). W tym duchu Pacewicz stwierdza, że to zdanie może być interpretowane zarówno pod względem ilościowym, jak i nieilościowym. W pierwszym przypadku chodziłoby o stwierdzenie: $w$ jakim stopniu jest coś przyjemne, w takim i dobre. Natomiast w drugim: „pod jakim względem coś jest przyjemne, pod tym względem jest też dobre” (A. Pacewicz, Hedone. Koncepcja przyjemności w filozofii Platona, dz. cyt., s. 179). Zeyl wspomina o ilościowej i jakościowej korelacji między byciem miłym i byciem dobrym w przypisie 11 swojego artykułu (Socrates and Hedonism: „Protagoras” 351b-358d, dz. cyt., s. 266). 
omawianego wyżej założenia, że warunki, dzięki którym coś jest przyjemne, a w konsekwencji dobre, dotyczą pewnego zakresu lub czasu. Tak więc stwierdzenie: o ile ( $\kappa \alpha \theta$ ’ ö $\sigma o \nu)$ coś jest przyjemne, jest również dobre ( $\alpha \gamma \alpha \theta$ ó $\nu)$, nie ma na uwadze wykazywania, że jakaś rzecz jest sama w sobie przyjemna czy też nie, ale wykazania słuszności przyjmowania związku przyjemności z dobrem. Ten zamiar wyraża ostania część zdania, gdzie Sokrates pyta o przyjemność samą (

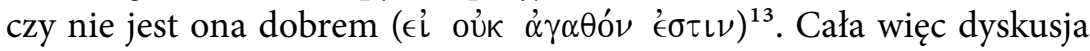
prowadzona w tej części dialogu przez Sokratesa i Protagorasa miałaby doprowadzić do wykazania ${ }^{14}$, że przyjemność jest związana $\mathrm{z}$ dobrem ${ }^{15}$.

Skoncentrowanie przez Sokratesa uwagi na przyjemności samej, a nie na rzeczach przyjemnych, może mieć swoje uzasadnienie w poglądach Protagorasa. Platon w dialogu Teajtet podejmuje się, ustami Sokratesa, próby skomentowania zachowanej tezy Protagorasa z jego dzieła Prawda lub mowy obalające, która według Platona brzmi: „wszystkich rzeczy $(\chi \rho \eta \mu \alpha \tau \tau \omega \nu)$ miarą jest człowiek, tych będących, że są, tych zaś niebędących, że nie są"16 w następujący sposób: „nie można bowiem mniemać o niebędących, ani o innych niż o tych, które się czuje, te zawsze

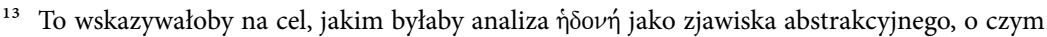

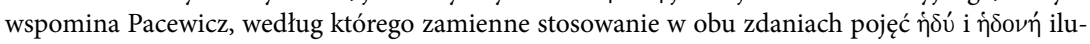
struje to, że „że Sokrates/Platon dopuszcza rozwój dyskusji zarówno w odniesieniu do obszaru bytów konkretnych, jak i zjawiska abstrakcyjnego, w zależności od tego, na jakie tory skieruje dyskusję współrozmówca" (A. Pacewicz, Hedone. Koncepcja przyjemności w filozofii Platona, dz. cyt., s. 180).

14 Mogłoby to się zgadzać z sugestią Diogenesa Laertiosa, według którego Protagoras Platona

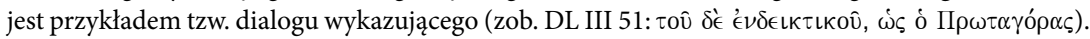

15 Sullivan sugeruje, że Sokrates przez to pytanie oczekuje twierdzącej odpowiedzi, „że przyjemności jako przyjemności są dobre” (J. P. Sullivan, The Hedonism in Plato’s „Protagoras”, dz. cyt., s. 21). Wcześniej podobną opinię wyraził Goodell, według którego Platon ustami Sokratesa wyjaśnia, że przyjemność w sobie (pleasure in itself) jest dobrem (zob. T. D. Goodell, Plato’s Hedonism, dz. cyt., s. 26).

16 Zob. Plato, Theaetetus, w: Platonis Opera, vol. 1, ed. J. Burnet, Oxford 1905, 152a 2-4 (=DK

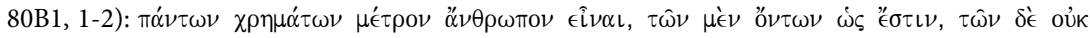

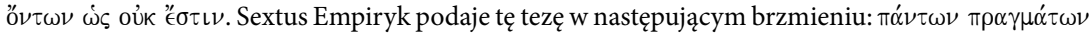

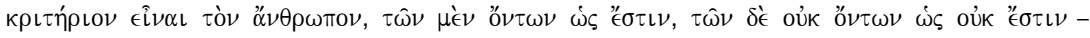
„wszystkich rzeczy kryterium jest człowiek, będących, że są, niebędących, że nie są” (Sextus Empiricus, PURWNEIWN UPOTUPWSEWN, 1, 216). 
są prawdziwe" ${ }^{17}$. Istotną rolę w ujmowaniu rzeczywistości odgrywa więc $\pi \alpha ́ \sigma \chi \epsilon \iota \nu$, czyli czucie, które zawsze jest prawdziwe $\left(\dot{\alpha} \lambda \eta \theta^{\prime} \epsilon\right)$. Wszystko bowiem, co oddziałuje na człowieka, jest przez niego odczuwane

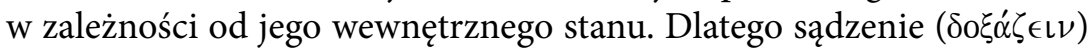
człowieka na temat tego, co jest doznawane, opiera się na czuciu posiadającym cechę prawdziwości. O czuciu $(\pi \alpha \dot{\sigma} \sigma \in \iota \nu)$ jest również mowa w dialogu Protagoras w kontekście tego, co przyjemne (íjú). Wspomina o tym Prodikos w słowach: „doznawanie przyjemności jest [wtedy], gdy coś jemy, albo coś innego przyjemnego odczuwamy samym ciałem"18.

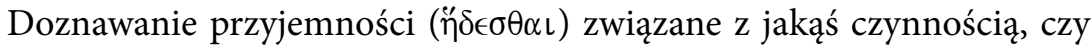

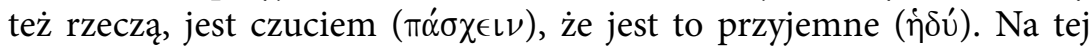
właśnie podstawie jest wydawany sąd, że coś jest przyjemne. Jednakże ta sama czynność lub rzecz może być określana przeciwnie w wyniku odmiennego stanu człowieka. W przypadku jedzenia może to być cho-

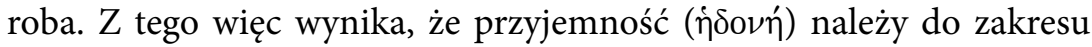
czucia ( $\pi \dot{\alpha} \sigma \chi \epsilon \nu \nu)$ uzależnionego od stanu człowieka. W kontekście wypowiedzi Prodikosa powstaje jednak pytanie, czy przyjemność, o której

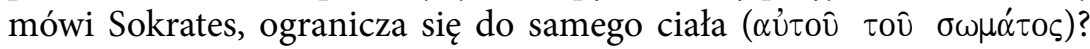
Opinie na ten temat są podzielone. Według Goodella termin przyjemność jest używany w najszerszym możliwym zastosowaniu, zawierającym również najwyższy rodzaj przyjemności ${ }^{19}$. Pogląd o szerszym użyciu terminu przyjemności przez Sokratesa podziela również Pacewicz ${ }^{20}$.

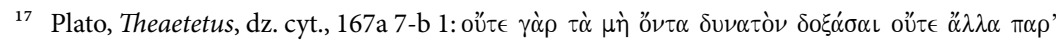

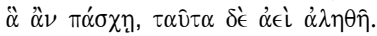

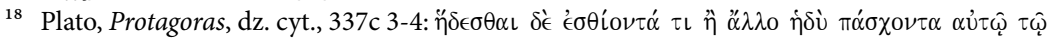
$\sigma \omega ́ \mu \alpha \tau$.

19 Zob. T. D. Goodell, Plato's Hedonism, dz. cyt., s. 26.

20 Zob. A. Pacewicz, Hedone. Koncepcja przyjemności w filozofii Platona, dz. cyt., s. 189: „(...) warto zwrócić uwagę na prolog i zakończenie dialogu. Sokrates, spotykając się z przyjacielem, zostaje poproszony o opowiedzenie o dyskusji z sofistą i nie tylko czerpie radość [charis] z opowiadania, lecz, dostrzegając chęć wysłuchania, stwierdza, że w ten sposób owa radość zostaje podwojona [diple charis] (Prt. 310a 5-7). Jak już wiemy, Sokrates odżegnuje się od Prodikosowego zbędnego rozróżniania wyrazów, a więc możemy przyjąć, że radość może być utożsamiona z przyjemnością. Nie wydaje się więc, iżby chodziło o przyjemność wyłącznie cielesną (być może timbre głosu Sokratesa budził odczucie przyjemności w słuchaczach), lecz byłaby to jednak przyjemność moralno-intelektualna. Podobnie na końcu Sokrates zwraca uwagę na konieczność przedyskutowania kwestii, 
Natomiast Sullivan zwraca uwagę, że wyższa przyjemność duszy, o której pisze Goodell, nie jest $w$ tym dialogu wspomniana. Według niego jest tu mowa raczej o zwykłych przyjemnościach przeciętnego obywatela ${ }^{21}$. Czy ta opinia mogłaby mieć swoje odzwierciedlenie w samym dialogu? Sokrates po rozpoczęciu dyskusji z Protagorasem na temat przyjemności stawia pytanie: ,jeżeli przyjemnie żyjąc, życie by zakończył, nie wydawałoby ci się tak, że dobrze żył?"22. W tym przypadku Sokrates

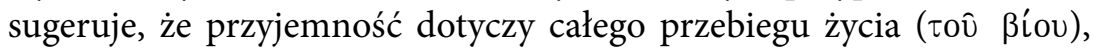
które nie musi sprowadzać się jedynie do doznań cielesnych, mających ograniczony zakres czasowy. W przypadku więc całego przebiegu życia należałoby mieć na uwadze pewien stan, w którym człowiek się znajduje. To natomiast jest związane raczej z zakresem postępowania etyczno-politycznego. Niezależnie jednak od tego, czego dotyczy przyjemność, w każdym przypadku jest to czucie ( $\pi \alpha ́ \sigma \chi \epsilon \iota \nu)$, które miałoby wskazywać na dobro ( $\alpha \gamma \alpha \theta$ óv). Czy jednak śledząc przebieg dyskusji Sokratesa z Protagorasem, będzie można wywnioskować, czego czuciem

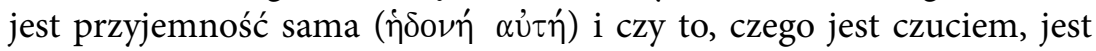
dobrem $(\dot{\alpha} \gamma \alpha \theta o ́ v)$ ?

\section{Powód mówienia o przyjemności, że jest dobrem}

Część dialogu, w której pojawia się sugestia, że przyjemność sama jest dobrem, rozpoczyna się od przytoczenia przez Sokratesa twierdzenia Protagorasa, że jacyś $(\tau \iota \nu \alpha \varsigma)$ ludzie $(\tau \hat{\omega} \nu \quad \dot{\alpha} \nu \theta \rho \omega \dot{\pi} \pi \omega \nu)$ żyją dobrze $(\epsilon \hat{U}$

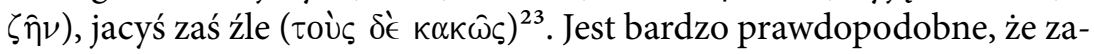

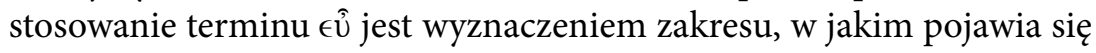
przyjemność. Sokrates bowiem, pytając Protagorasa o przeżycie życia

czym jest arete, a uczyniłby to z Protagorasem «z najwyższą przyjemnością» [hedista] (Prt. 361d 6). Również w tym przypadku trudno dopatrywać się przyjemności wyłącznie cielesnej”.

${ }^{21}$ Zob. J. P. Sullivan, The Hedonism in Plato’s „Protagoras”, dz. cyt., s. 10.

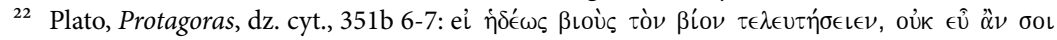

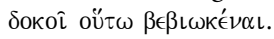

23 Zob. Plato, Protagoras, dz. cyt., 351b 3-4. 
przyjemnie ( $\left.\dot{\eta}^{\delta} \in \epsilon \omega \zeta\right)$, zestawia je najpierw $\mathrm{z} \in \hat{i}^{24}$. Rozpoznanie więc własności przyjemności wymaga zrozumienia, na czym polega życie chrakteryzujące się owym $\epsilon \hat{\jmath}$. Zeyl stwierdza, że $\epsilon \hat{\jmath} \zeta$

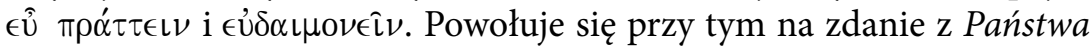
Platona i z Etyki nikomachejskiej Arystotelesa ${ }^{25}$. Platon w dialogu Państwo pisze: „Lecz kto dobrze żyje, błogi i szczęśliwy, kto zaś nie, przeciwnie"26. Platon uzależnia uzyskanie tego stanu od bycia sprawied-

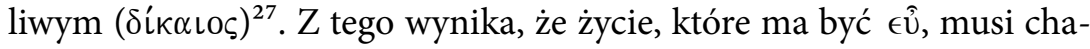
rakteryzować się właściwym sposobem postępowania powodującym, że człowiek staje się sprawiedliwym. Wydaje się, że między innymi taki

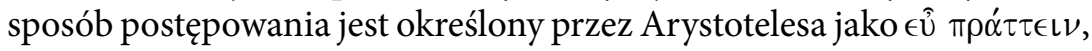

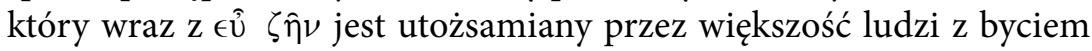
szczęśliwym $(\epsilon \cup ̉ \delta \alpha \iota \mu o \nu \in \hat{\imath} \nu)^{28}$. Sprowadzenie dobrego życia do bycia szczęśliwym może sugerować, że jest to życie, w którym człowiek ma poczucie spełnienia. Ktoś może czuć się spełniony w życiu zawodowym,

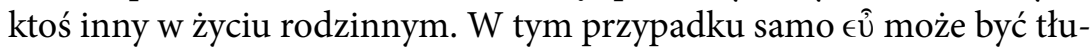
maczone jako „pomyślnie”. Czy takie znaczenie terminu $\epsilon u ̂$ może być przyjęte w kontekście prowadzonej dyskusji? Po przytoczeniu pierwszej tezy w kształcie pytania, Sokrates sugeruje zestawienie życia cechującego

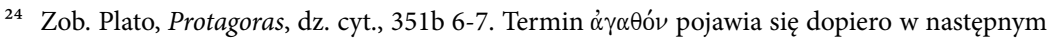
zdaniu, będącym posumowaniem dotychczasowego dialogu: „Więc może przyjemnie żyć to dobrze,

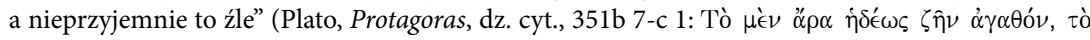

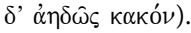

25 Zob. D. J. Zeyl, Socrates and Hedonism: „Protagoras” 351b-358d, dz. cyt., s. 252 i 256. W podobny sposób na temat $\epsilon \hat{̉} \zeta \hat{y} \nu$ wypowiada się Pacewicz: „Zwrot ten jest dwuznaczny i można go uznać za synonim pojęć «powodzenie w działaniu» oraz «szczęście»; zob. np. Platon, $R$. 354a: (...) oraz Arystoteles, EN 1095a 19-20: (...)" (A. Pacewicz, Hedone. Koncepcja przyjemności w filozofii Platona, dz. cyt., s. 177).

26 Plato, Respublica, w: Platonis Opera, vol. 4, ed. J. Burnet, Oxford 1905, 354a 1-2: 'A $\lambda \lambda \dot{\alpha} \mu \grave{\eta} \nu$

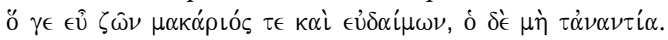

${ }^{27}$ Zob. Plato, Respublica, dz. cyt., 354a 4: 'O $\mu$ '̇ zatem, szczęśliwy".

28 Zob. Aristoteles Graece, ex rec. I. Bekkeri, vol. 2, Berolini 1831. Wydanie drugie, poprawione:

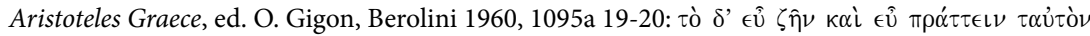

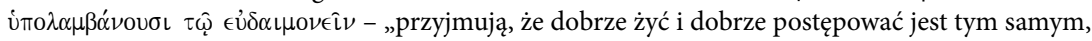
co być szczęśliwym". 


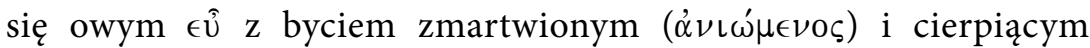

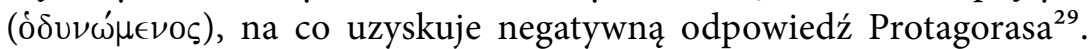
Człowiek, który jest zmartwiony, dostrzega, że coś przebiega nie tak, jak powinno, czyli nie jest pomyślne. Z brakiem pomyślności wiąże się również cierpienie, które jest pewnym obciążeniem czy też dolegliwością. Oba te określenia wskazują na stan ograniczenia, a w konsekwencji braku spełnienia. Można więc stwierdzić, że życie pomyślne to takie, w którym człowiek jest spełniony, czyli realizuje swój cel, jakim jest jego bycie. Doświadczenie spełnienia jest również związane z brakiem jakiegokolwiek obciążenia powodującego cierpienie. Stan pomyślnego życia jest rozpoznawany przez odczucie przyjemności. Można powiedzieć, że człowiek odczuwa przyjemność, doświadczając spełnienia i braku obciążenia. Nie jest więc możliwe życie pomyślne bez jednoczesnego odczuwania przyjemności. Mając na uwadze fakt, że czucie jest zawsze prawdziwe, należy uznać, że staje się ono informacją o stanie, w jakim człowiek się znajduje. Być może z tego powodu Sokrates w następnym pytaniu skierowanym do Protagorasa stwierdza, że [można uznać, że] człowiek żył $\left(\beta € \beta \iota \omega \kappa^{\prime} \in \alpha \iota\right)$ pomyślnie, wtedy kiedy okazuje się, że było to życie przyjemne ${ }^{30}$. Czy jednak pomyślne życie, z którym ściśle wiąże się odczucie

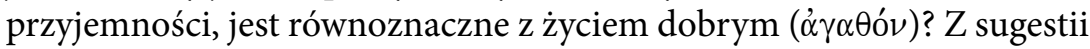
wyrażonej przez Sokratesa należałoby wyciągnąć wniosek twierdzący. Stwierdza bowiem: „więc przyjemnie żył to dobrze ( $\alpha \gamma \alpha \theta$ ó $\nu$ ”31. Jednakże w odpowiedzi Protagorasa na zaproponowany wniosek Sokratesa poja-

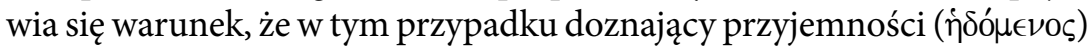

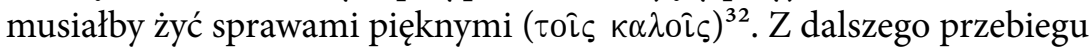
rozmowy może się wydawać, że Sokrates nie podejmuje od razu sugestii Protagorasa. Charles H. Kahn twierdzi bowiem, że „na wcześniejszym etapie dyskusji Sokrates uniemożliwił Protagorasowi odwoływanie się

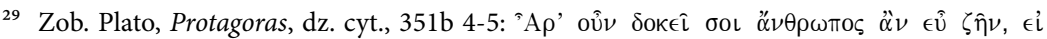

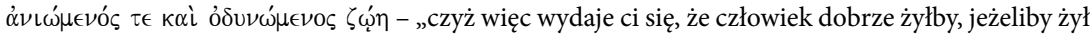
zmartwiony i cierpiący?"

30 Zob. Plato, Protagoras, dz. cyt., 351b 6-7.

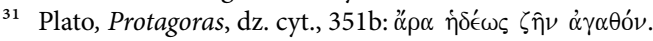

32 Zob. Plato, Protagoras, dz. cyt., 351c 1-2. 
do względów moralnych, oddanych w 351 c1 wyrażeniem ta kala, «rzeczy zaszczytne»" ${ }^{\prime 3}$. Jednakże to wrażenie nie jest do końca trafne. Wzmianka Protagorasa o tym, że o przyjemnym życiu, które można by nazwać dobrym, decydują sprawy piękne, wyznacza nowy kierunek dyskusji. Rozpoczyna się ona od sugestii nawiązującej do jego słów o zależności między przyjemnością będącą dobrem a sprawami pięknymi. Pogląd Protagorasa może bowiem sugerować, że nie wszystko, co jest przyjemne, jest dobre. $Z$ tego powodu Sokrates pyta Protagorasa, czy skłania się do opinii prezentowanej przez wielu ludzi, że pewne rzeczy przyjemne

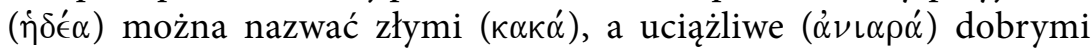
$(\dot{\alpha} \gamma \alpha \theta \dot{\alpha})^{34}$. Jeżeli bowiem odczucie przyjemne jest wynikiem pomyślności, to w jaki sposób to, co jest przyjemne, miałoby być czymś złym? Ocenia się bowiem, że coś jest przyjemne wtedy, kiedy jest pomyślne dla życia ludzkiego, czyli w ostateczności jest czymś dla niego dobrym. Sokrates, odpowiadając Protagorasowi, uwzględnia ten właśnie punkt widzenia. Nie może bowiem mówić o czymś przyjemnym, jeżeli to coś nie prowadzi do pomyślności. $Z$ tego powodu to, co jest przyjemne, jest również dobre ${ }^{35}$. Sokrates, podtrzymując ten pogląd, podejmuje wysiłek wykazania błędności powszechnie przyjmowanej opinii, do której skłania się Protagoras, i poprawności tezy Protagorasa, że człowiek doznaje przyjemności jako dobra, gdy żyje sprawami pięknymi. Rozpoczyna od założenia, na które zgadza się również Protagoras, że przyjemnymi

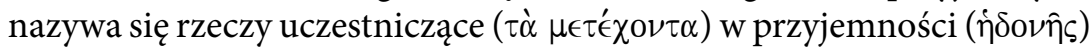

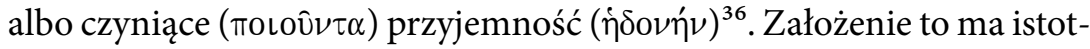
ne znaczenie dla dalszego toku rozumowania. Sokrates zwraca bowiem uwagę, że o czymś przyjemnym można mówić jedynie wtedy, gdy powoduje samą przyjemność. Jeżeli więc w jakimś momencie lub okoliczności to, co powodowało przyjemność, już jej nie czyni, to nie można mówić o nim, że jest przyjemne. Sama natomiast przyjemność jako taka nigdy

33 Ch. H. Kahn, Platon i dialog sokratyczny, dz. cyt., s. 388.

34 Zob. Plato, Protagoras, dz. cyt., 351c 2-3.

35 Zob. Plato, Protagoras, dz. cyt., 351c 4-5.

36 Zob. Plato, Protagoras, dz. cyt., 351d 7-e 1. 
nie przestaje być przyjemnością. Mając na uwadze fakt, że odczucie przyjemności jest ściśle związane z pomyślnością, czyli szczęściem, Sokrates

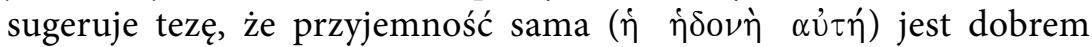
$(\alpha \gamma \alpha \theta \text { ó } \nu)^{37}$. Jest to pierwsza sugestia skierowana w stronę Protagorasa

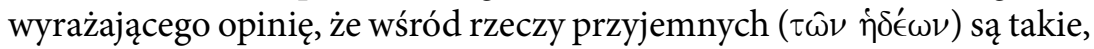

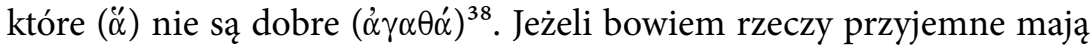
być uznane za dobre, to według Protagorasa muszą być piękne. Wydaje się, że w dalszej części dyskusji Sokrates próbuje ustosunkować się do za-

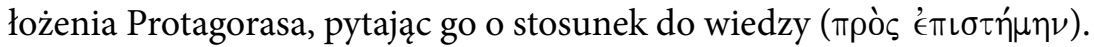
Zanim jednak otrzyma od Protagorasa odpowiedź, przedstawia mniemanie wielu ludzi na jej temat. Czyni to, mając na uwadze sugestię Protagorasa, opartą na powszechnej opinii o rzeczach przyjemnych niebędących dobrymi. Według wielu ludzi bowiem wiedza ( $\dot{\eta} \epsilon \pi\llcorner\sigma \tau \eta \dot{\eta} \mu \eta)$ nie

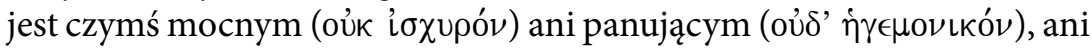

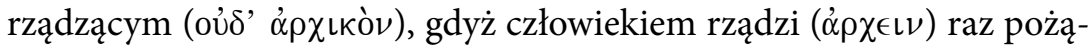

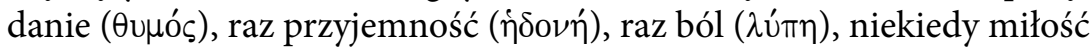

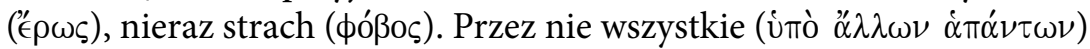

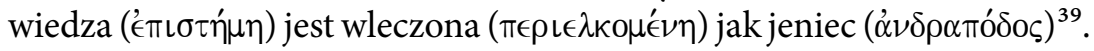
W ten sposób Sokrates wskazuje na powód powstawania opinii, że rzeczy przyjemne mogą nie być dobre. Człowiek, kierując się chęcią odczucia przyjemności, czyni coś, co mogło być uznane za przyjemne, ale w danych okolicznościach nie doprowadza do stanu, który odczuwany jest jako przyjemny. Opinii wielu ludzi Sokrates przeciwstawia rozumie-

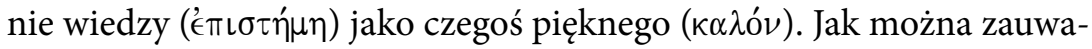
żyć, propozycja ta jest odpowiedzią na postulat Protagorasa, że doznający przyjemności musiałby żyć sprawami pięknymi, jeżeli życie przyjemne miałoby być dobre. To natomiast, z jakiego powodu wiedzę należy uznać za coś pięknego, Sokrates wyjaśnia, twierdząc, że wiedza może rządzić

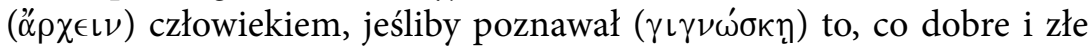

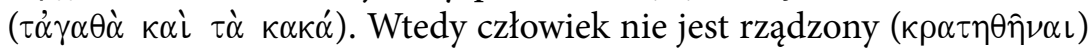

37 Zob. Plato, Protagoras, dz. cyt., 351e 2-3.

38 Zob. Plato, Protagoras, dz. cyt., 351d 4-5.

39 Zob. Plato, Protagoras, dz. cyt., 352b 3-c 2. 


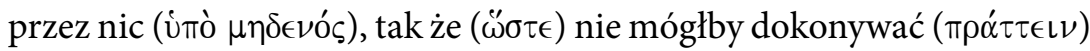

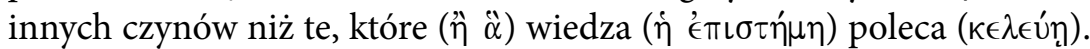
Do tego zaś wystarczający jest rozum ( $\tau \grave{\eta} \nu$ $\phi \rho o ́ \nu \eta \sigma \iota \nu)$, by pomagać $(\beta o \eta \theta \in \hat{\imath} \nu)$ człowiekowi $(\tau \hat{\omega} \dot{\alpha} \nu \theta \rho \omega \dot{\pi} \pi \omega)^{40}$. Z tego wynika, że działanie na podstawie wiedzy o tym, co jest dobre, jest w rzeczywistości dobrym i w konsekwencji przyjemnym. Wspomniany przez Sokratesa rozum, mający pomagać człowiekowi, odgrywa istotną rolę w zdobywaniu wiedzy dotyczącej tego, co jest dobre, a w konsekwencji przyjemne. Celem rozumowania jest bowiem rozpoznanie, jakie działanie będzie pomyślne dla człowieka. Osiągnięcie tego stanu skutkuje bowiem czuciem, jakim jest przyjemność, będąca przeciwieństwem zmartwienia i cierpienia. Lekceważenie więc wiedzy przy dążeniu do stanu gwarantującego przyjemność może doprowadzić do odwrotnego skutku oraz nieuprawnej opinii, że coś przyjemnego może być złe. Po zaprezentowaniu Protagorasowi tych dwóch poglądów Sokrates podejmuje próbę uzasadnienia błędności pierwszego i słuszności drugiego.

\section{Przezwyciężenie opinii podważającej tezę, że przyjemność sama jest dobrem}

Z dotychczasowych analiz wynika, że powodem uznawania czegoś przyjemnego za złe jest postawa ludzi wobec wiedzy, traktowanie jej jako jeńca. Sokrates zwraca uwagę, że tacy ludzie twierdzą, iż znając

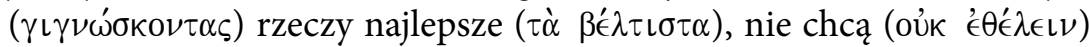
ich dokonywać ( $\pi \rho \alpha \dot{\alpha} \tau \tau \in \iota \nu)$, choć mogą, lecz innych dokonują ( $\alpha \lambda \lambda^{\prime}{ }^{\prime \prime} \alpha \lambda \lambda \alpha$

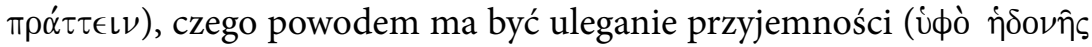
$\dot{\eta} \tau \tau \hat{\alpha} \sigma \theta \alpha \iota)^{41}$. W tym sposobie rozumowania ujawnia się również to, że nie tylko coś, co było nazwane jako przyjemne, staje się złym, ale sama przyjemność jest powodem dystansowania się wobec tego, co jest najlepsze. Jest to więc opinia, która podaje w wątpliwość tezę Sokratesa, że przyjemność sama jest dobrem. Źródłem tej opinii jest uznawanie

40 Zob. Plato, Protagoras, dz. cyt., 352c 2-7.

41 Zob. Plato, Protagoras, dz. cyt., 352d 6-e 2. 
przez ludzi, że decydujący wpływ na postępowanie człowieka ma stan nazywany przez nich uleganiem przyjemności. Dlatego Sokrates podejmuje wysiłek przeanalizowania ich sposobu rozumowania. Już od samego początku swojego wywodu zdaje się zwracać uwagę na to, co powoduje formułowanie niewłaściwych sądów na temat przyjemności,

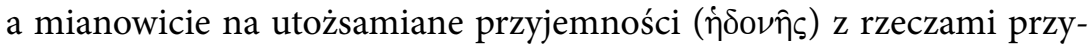
jemnymi ( $\left.\delta_{\delta} \epsilon \omega \nu\right)$. To bowiem, co jest nazywane przez wielu uleganiem

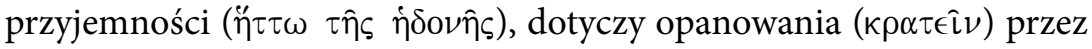

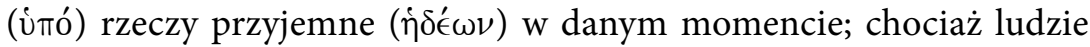

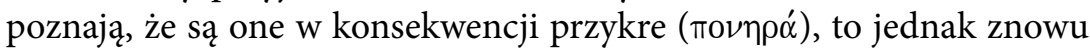
to czynią ${ }^{42}$. Decydującą rolę odgrywa jednak nie tyle opanowanie przez

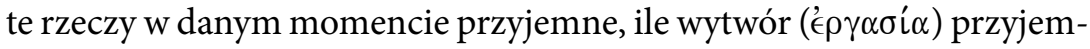
ności, która w tej chwili jest doznawana, co powoduje, że nie są brane

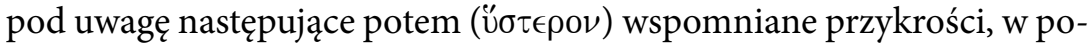

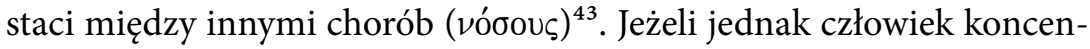
truje się na samej przyjemności, to można przypuszczać, że doznawanie

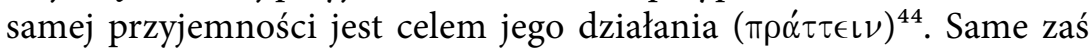
rzecz lub zdarzenie są jedynie środkiem do uzyskania tego celu. Problem tkwi w tym, że odczucie przyjemności ustaje i jest zastąpione udręką $(\dot{\alpha} \nu i ́ \alpha)$, którą uznaje się za coś złego $(\kappa \alpha \kappa o \nu)^{45}$. Można więc zauważyć,

42 Zob. Plato, Protagoras, dz. cyt., 353c 1-8.

43 Zob. Plato, Protagoras, dz. cyt., 353d 7-e 1.

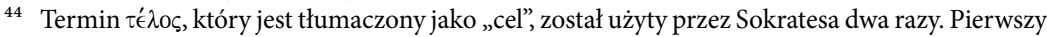

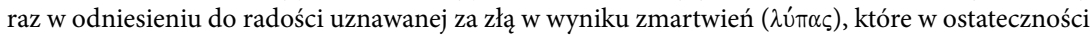
się pojawiają (zob. Plato, Protagoras, dz. cyt., 354d 1-2). Drugi raz, gdy ludzie o doznawaniu bólu

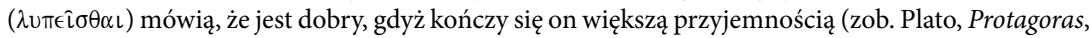

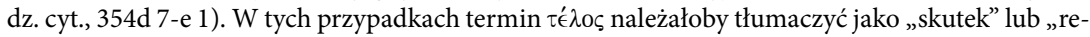
zultat". Zastosowany więc w obu przypadkach termin $\tau$ t'́ $\lambda$ o nie jest w tym kontekście równoznaczny z rozumieniem go jako celu, do którego dąży człowiek, jak to sugeruje Pacewicz, pisząc: „Z jednej strony uzasadniona jest interpretacja telos $\mathrm{w}$ kategoriach celu, i to prawdopodobnie celu jedynego oraz ostatecznego. Przyjemność stanowiłaby więc teleologiczny determinant natury ludzkiej, określający działanie człowieka w szczególności w sferze etycznej. Byłaby również dobrem (por. Grg. 499e) lub dobrem najwyższym (jeśli przyjmiemy, że istnieje jakaś zhierarchizowana klasa dóbr), a być może również gwarantem życia szczęśliwego" (A. Pacewicz, Hedone. Koncepcja przyjemności $w$ filozofii Platona, dz. cyt., s. 181).

45 Zob. Plato, Protagoras, dz. cyt., 353e 5-354a 1. 
że odczucie przyjemności będące wynikiem jakiejś rzeczy lub zdarzenia charakteryzuje się pewnym czasem trwania. Jeżeli więc to odczucie ustanie, to w kontekście następującej po niej udręce zdarzenie lub rzecz, które miały zapewnić przyjemność, uznawane są za złe. W tej sytuacji pojawia się opinia o uleganiu przyjemności, jako czemuś niezwiązanemu z dobrem. Niemniej jednak w opinii wielu, jak zauważa Sokrates, intuicja związku przyjemności z dobrem jest widoczna. Według nich

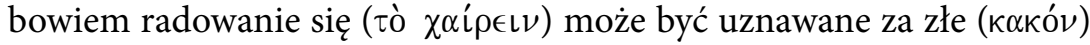

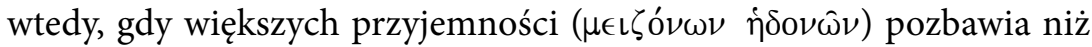
przysparza $^{46}$. Z tego wynika, że miarą radości dobrej lub złej staje się zakres towarzyszącej jej przyjemności, która jest dobra. Potwierdzeniem, że przyjemność jest dobra, może być również opinia ludzi o dobrym smuceniu się ( $\lambda \cup \pi \epsilon i \sigma \sigma \theta \alpha \iota ~ \alpha ̉ \gamma \alpha \theta o ́ v)$, które jest takim, gdy sprawia większe

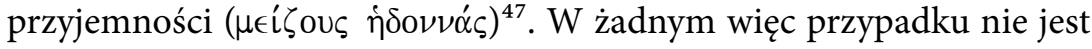
możliwe uznawanie jakiejkolwiek przyjemności za zło. $Z$ tego wynika,

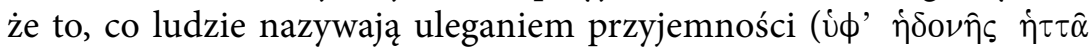
$\sigma \theta \alpha \iota)$, jest w rzeczywistości dążeniem ( $\delta\llcorner\omega ́ \kappa \in \iota \nu)$ do celu, jakim jest sama przyjemność będąca doznaniem dobra ${ }^{48}$. Z tego też powodu twierdzenie, że człowiek, poznając, co jest złe, czyni ( $\pi \rho \alpha ́ \tau \tau \epsilon \iota)$ zło dlatego, że jest pro-

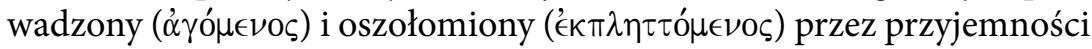

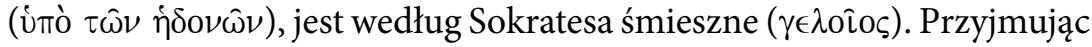
bowiem tę tezę za słuszną, należałoby uznać, że przyjemności prowadzą do złego, czyli można by mówić o ich złym charakterze. Według ogółu ludzi taką tezę mogłaby uzasadniać sytuacja, w której człowiek, poznając

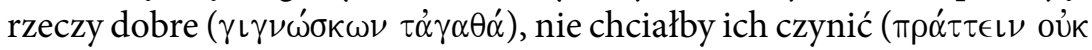

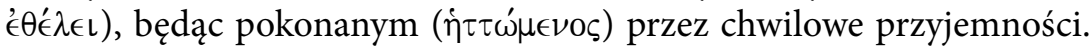

46 Zob. Plato, Protagoras, dz. cyt., 354c 5-d 1.

47 Zob. Plato, Protagoras, dz. cyt., 354d 4-7.

48 Na takie odniesienie do przyjemności wskazuje Sokrates w pytaniu skierowanym do ludzi przyjmujących pogląd o uleganiu przyjemności: „czyż nie do przyjemności dążycie, bo to do-

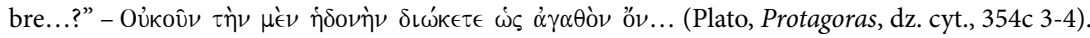
Również Oded Balaban sugeruje, że stwierdzenie „być pokonanym przez przyjemność” jest jedynie interpretacją, która nie odnosi się do żadnego takiego zjawiska, gdyż takiego zjawiska nie ma (zob. O. Balaban, Plato and Protagoras. Truth and Relativism in Ancient Greek Philosophy, Lexington Books 1999, s. 255). 
Jeżeli jednak przyjemność sama jest doznaniem dobra, to uznawanie jej za coś przeciwnego dobru byłoby czymś śmiesznym ${ }^{49}$. Jeżeli więc dążenie do przyjemności miałoby skutkować sytuacją, w której nie pojawia się po niej jakieś obciążenie, to za przewodnika należy mieć wiedzę

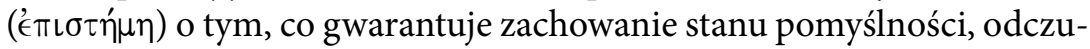
wanej jako przyjemność, czyli brak niepokojów, w całym życiu.

\section{Znaczenie wiedzy mierniczej dla uzyskania spokoju i zachowania życia}

W dalszej części Sokrates ukazuje, w jaki sposób jest możliwe do osiągnięcia największe odczucie przyjemności, czyli obecne w całym życiu, a nie tylko przez jakiś czas. Jest to przedsięwzięcie o tyle istotne, że w ostateczności może obronić tezę o nierozerwalnym związku przyjemności z dobrem, który jest podważany przez wybór tego, co nie gwarantuje długotrwałej pomyślności. Taką gwarancję może zapewnić jedynie postępowanie, które w efekcie kończy się odpowiednio długim odczuciem przyjemności. Opinia ludzi o wyborze większych przyjem-

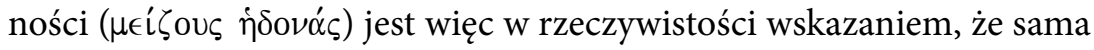
przyjemność jest dobra. Natomiast sugestia o negatywnym skutku przyjemności wynika $\mathrm{z}$ wyboru postępowania niosącego ze sobą krótkotrwałe odczucie przyjemności, po którym następuje niepokój i ból. Ta krótkotrwałość powoduje, że człowiek nie uzyskuje trwałego stanu pomyślności odczuwanego jako przyjemność, do którego dąży. Aby

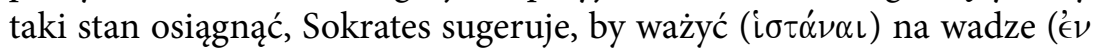

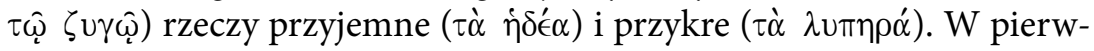
szym przypadku należy wybierać te, których jest więcej $(\pi \lambda \in i \omega)$ i które są większe $(\mu \epsilon i \zeta \zeta \omega)$, a w drugim mniejsze ( $\sigma \mu \iota \kappa \rho o ́ \tau \epsilon \rho \alpha)$ i których jest mniej ( $\dot{\epsilon} \lambda \dot{\alpha} \tau \tau \omega)$. Jeżeli zestawione są ze sobą rzeczy przyjemne i przykre, to wybierać należy tylko te, w których przeważa to, co jest przyjemne, a unikać tych, w których przewagę zdobywa to, co jest przykre. Ten sposób zestawiania i ważenia rzeczy przyjemnych i przykrych jest bardzo

49 Zob. Plato, Protagoras, dz. cyt., 355a 5-c 1. 
istotny w kontekście tego, co jest blisko (

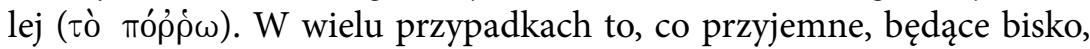
w konsekwencji zostanie przeważone przez to, co przykre, będące dalej, i odwrotnie, to, co jest przykre, będące blisko, w efekcie jest przeważone przez to, co przyjemne, będące dalej. Zawsze należy wybierać ten przypadek, w którym przeważa to, co przyjemne, i takiego dzieła na-

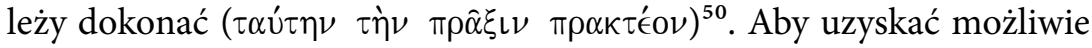
najdłuższy stan pomyślności przez dokonywanie wspomnianych dzieł, konieczne jest, by w wyborze działania gwarantującego taki stan (

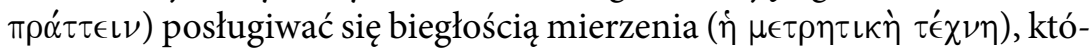

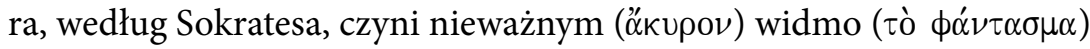
mające zwodniczy charakter doprowadzający w ostateczności do żalu $\left(\mu \epsilon \tau \alpha \mu \mu^{\prime} \lambda \epsilon \iota \nu\right)$. Samo więc miernictwo (†் $\left.\mu \epsilon \tau \rho \eta \tau \iota \kappa \eta ́\right)$ pozwala wybierać zawsze to, dzięki czemu możliwy jest spokój (

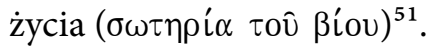

Miernictwo zastosowane przez Sokratesa do osiągnięcia największej przyjemności jest odwołaniem się do wspomnianej już tezy Protagorasa,

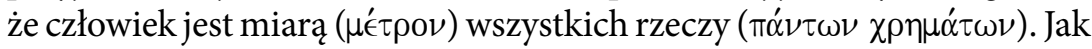
jednak należy rozumieć ten zabieg Sokratesa? Według Pacewicza Sokrates poprzez zaproponowanie biegłości mierzenia, będącej jednocześnie wiedzą, chciał zapobiec niebezpieczeństwu traktowania człowieka jako miary $^{52}$. Wydaje się jednak, że wspomniane przez Sokratesa zachowanie

50 Zob. Plato, Protagoras, dz. cyt., 356a 8-c 1.

51 Zob. Plato, Protagoras, dz. cyt., 356c 8-e 4.

52 Zob. A. Pacewicz, Hedone. Koncepcja przyjemności w filozofii Platona, dz. cyt., s. 184: „Platoński Sokrates zdaje sobie sprawę z tego, że jeśli akceptujemy względność czegokolwiek, to może ona być interpretowana w sposób subiektywny (Prt. 356c), to znaczy sugerowany między innymi przez słynną Protagorasową tezę homo-mensura: «człowiek jest miarą wszystkich rzeczy [chremata], tych które są, jak są, tych które nie są, jak nie są» (DK 80B 1). W wypadku przyjemności i doznawania bólu również mamy do czynienia z mierzeniem, a więc istniałoby niebezpieczeństwo, że rolę miary spełniać miałby człowiek. W takim, wyłącznie podmiotowym ujęciu, mamy jednak do czynienia ze sferą tego, co się jawi [to phainomenon], a co stanowi również swoistą ułudę [phantasma], która posiada właściwą sobie, prawdopodobnie dużą, moc czy też władzę oddziaływania (dunamis Prt. 356d 4; kuros - Prt. 356d 8). W celu zapewnienia sobie dobrego, słusznego i pomyślnego działania [eu prattein], co ma skutkować ocaleniem życia [soteria tou boiu], należy odwołać się więc 
( $\left.\sigma \omega \tau \eta i^{\prime} \alpha\right)$ życia, będące efektem posługiwania się w wyborze pomyślnego postępowania biegłością mierniczą może wskazywać właśnie na to, iż miarą jest sam człowiek. W jego życiu bowiem chodzi o zachowanie samego siebie i osiągnięcie spokoju, który wyraża się stanem pomyślności. Sama więc biegłość miernicza ma doprowadzać w konsekwencji do takich działań, które zagwarantują ową pomyślność w całym życiu człowieka. Takiej gwarancji nie dają ani jedzenie, ani pice, ani tym podobne, gdyż odczucie przyjemności wynikające $\mathrm{z}$ ich zaspokojenia nie jest trwałe. Człowiek bowiem przez jedzenie wyzwala się z ucisku głodu, jednakże stan zachowania życia trwa jedynie przez pewien czas. Próba wyzwolenia się na dłuższy czas przez przyjmowanie większej ilości pokarmu kończy się obciążeniem wynikającym z przejedzenia. Podobna trudność w uzyskania trwałego spokoju i zachowania życia występuje w gromadzeniu bogactwa, które miałoby być gwarantem pomyślności. Koncentrowanie się na bogactwie, które jest zależne od wielu uwarunkowań zewnętrznych, nie niesie ze sobą spokoju, a zachowanie życia jest złudne. Można więc zauważyć, że złudzenie ( $\tau$ ò $\phi \alpha ́ v \tau \alpha \sigma \mu \alpha)$ dotyczy nieuprawnionego nadawania temu, co powoduje odczucie przyjemności tylko w ograniczonym zakresie, znaczenia trwałości, którą powinna charakteryzować się przyjemność wynikająca ze stanu pomyślności właściwego dla całego przebiegu życia człowieka. W przypadku pojawiającego się odczucia obciążenia lub utrapienia pojawia się kolejne złudzenie, że przyjemność jest zła. Wyzwoleniem ze złudzeń może być jedynie uzyskanie wiedzy $(\stackrel{\epsilon}{\epsilon} \iota \sigma \tau \eta \dot{\eta} \mu \eta)$ będącej wynikiem biegłości mierniczej ( $\mu \in \tau \rho \hat{\eta}$

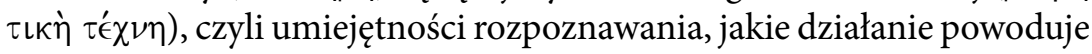
uzyskanie możliwie największej przyjemności, będącej wyrazem spokoju i zachowania życia ${ }^{53}$. Należy przy tym zwrócić uwagę, że człowiek nawet wtedy, gdy nie kieruje się biegłością mierniczą i wiedzą, nie rezygnuje $\mathrm{z}$ odniesienia do samego siebie, czyli cały czas jest obecna $\mathrm{w}$ nim chęć zachowania życia i uzyskania spokoju. Jednakże w tym przypadku

do odpowiedniego narzędzia, którym jest umiejętność miernicza [techne metretike], będąca jednocześnie wiedzą (Prt. 356c-357a)".

${ }^{53}$ Zob. Plato, Protagoras, dz. cyt., 357b 4. 


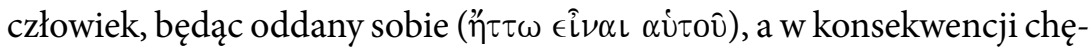
ci osiągnięcia stanu gwarantującego przyjemność w całym życiu, może popełnić błąd, podejmując czyn, który tu i teraz powoduje przyjemność, chociaż jest ona tylko chwilowa, a więc, jak przedstawia to Sokrates, czło-

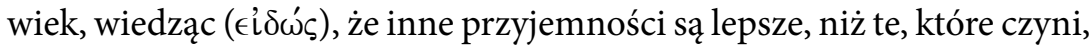
jednak je czyni. Taka postawa jest uznawana za głupotę ( $\alpha \mu \alpha \theta i \alpha \nu)$. Prze-

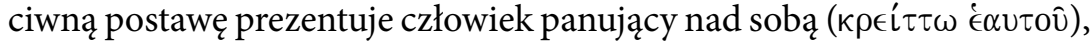

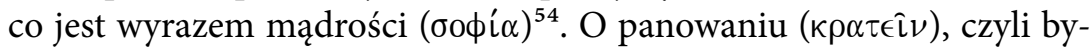

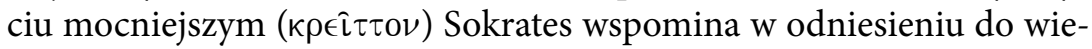

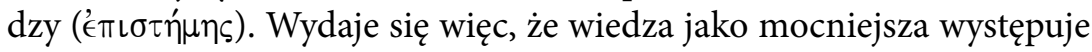
wtedy, kiedy człowiek panuje nad sobą. Jeżeli bowiem chodzi mu o to, by uzyskać stan pomyślności, charakteryzujący się osiągnięciem spokoju i zachowania życia, to musi on panować nad sobą samym, kierując się wiedzą o tym, jakie postępowanie będzie najlepsze. W ten właśnie spo-

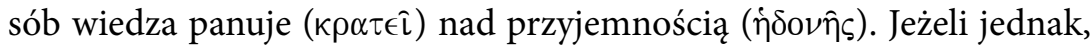
jak przedstawia to powszechna opinia ludzi, przyjemność panuje nad wiedzącym człowiekiem ( cenia wiedzy $(€ \in \leftarrow \sigma \tau \eta \dot{\eta} \mu \eta)^{55}$. Nie można zatem uzyskać trwałego spokoju i ocalić życia, jeżeli człowiek skupi się na postępowaniu powodującym taki stan chwilowo. Dlatego istotne jest, by za pomocą wiedzy nabytej $\mathrm{w}$ wyniku mierzenia, rozpoznać, które z postępowań będą odpowiednie do zachowania jestestwa $\mathrm{z}$ natury swojej trwałego, co wyraża się stanem pomyślności odczuwanym jako przyjemność.

Z przeprowadzonych analiz można wywnioskować, że Sokrates, koncentrując się na odczuciu przyjemności jako na czymś zawsze prawdziwym, co wynika z interpretacji tezy Protagorasa, próbował wykazać, czego to odczucie rzeczywiście dotyczy. Już bowiem od samego początku zestawiał przyjemność z pomyślnym ( $\epsilon \hat{)}$ życiem. Można więc powiedzieć, że człowiek, chcąc odczuwać przyjemność, musi zabiegać

54 Zob. Plato, Protagoras, dz. cyt., 358b 6-c 3.

55 Zob. Plato, Protagoras, dz. cyt., 357c 1-8. 
o pomyślność. Sokrates zdaje się w swojej dyskusji z ogółem ludzi sugerować zabieganie o przyjemność, a nie pomyślność. Nie wydaje się, żeby to była istotna trudność. Jeżeli bowiem przyjemność ma być dobrem, to jako odczucie musi wyrażać stan pomyślności. Problem jednak pojawia się wtedy, gdy odczucie przyjemności nie jest trwałe i zamienia się w zmartwienie lub cierpienie. To doświadczenie doprowadza do stwierdzenia, że sama przyjemność może nie być czymś dobrym. Z tego też powodu dążenie do przyjemności jest fałszywie uznawane za uleganie. Jak można zauważyć, faktycznym powodem takiej opinii jest krótkotrwałość odczucia przyjemności lub jej brak. Jeżeli więc rzeczywistym dążeniem jest odczuwanie przyjemności w sposób trwały, to jest to wskazówka, że przyjemność odnosi się do dobra człowieka, czyli uzyskania stanu pomyślności w całym jego życiu. Sama pomyślność, jak się zdaje, jest związana z zachowaniem ( $\left.\sigma \omega \tau \eta \rho^{\prime} \alpha\right)$ życia i spokojem ( cechy właściwe dla odczuwania przyjemności, gdyż sama przyjemność jest przeciwstawiana niepokojowi i bólowi. $Z$ tego też powodu postępowanie człowieka, które $\mathrm{w}$ efekcie ma być przyjemne, musi być pożyteczne $(\dot{\omega} \phi \dot{\epsilon} \lambda \iota \mu \nu \nu)^{56}$ dla niego samego. Człowiek, postępując w sposób pożyteczny, odwołuje się więc do siebie samego. Jednakże, jak zauważa Sokrates, to odniesienie do siebie samego nie może być uleganiem sobie

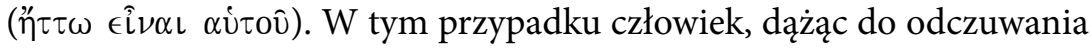
przyjemności z pomyślnego życia, koncentruje się na tym, co wydaje się powodować taki stan w konkretnym momencie. Taka postawa nie gwarantuje trwałego zachowania siebie oraz spokoju, czyli stanu pomyślności w całym życiu. Jest to możliwe do osiągnięcia jedynie wtedy, kiedy

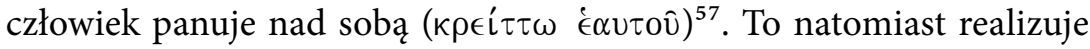
się przez wybór sposobu działania gwarantującego pomyślność w całym życiu, a tym samym odczuwanie największej przyjemności. Człowiek winien więc mierzyć, czy też ważyć, które z postępowań przyniesie

56 Zob. Plato, Protagoras, dz. cyt., 358b 5-6.

57 Można w tym przypadku odwołać się do wcześniejszej mowy Protagorasa dotyczącej na-

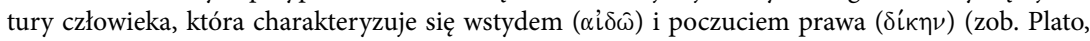
Protagoras, dz. cyt., 322c 2). 
pożądany efekt. Dlatego też Sokrates akcentuje rolę biegłości mierniczej i związanej z nią wiedzy w dążeniu do największej przyjemności, która w najlepszy sposób dowodzi związku z dobrem. Przyjmując tę perspektywę rozumienia dyskusji Sokratesa z Protagorasem i ogółem ludzi, można przypuszczać, że wykazanie związku przyjemności z pomyślnym życiem, będącym wynikiem postępowania gwarantującego zachowanie życia i spokój dyszy, staje się punktem wyjścia do odpowiedzi na pytanie, jaki rodzaj postępowania zapewnia trwałą pomyślność, czyli szczęście.

\section{Bibliografia}

Aristoteles Graece, ex rec. I. Bekkeri, vol. 2, Berolini 1831. Wydanie drugie, poprawione: Aristoteles Graece, ed. O. Gigon, Berolini 1960.

Balaban O., Plato and Protagoras. Truth and Relativism in Ancient Greek Philosophy, Lexington Books 1999.

Goodell T. D., Plato's Hedonism, „The American Journal of Philology” 42 (1921) No. 1, s. 25-39.

Hackforth R., Hedonism in Plato's Protagoras, „Classical Quarterly” 22 (1928), s. 39-42.

Kahn Ch. H., Platon i dialog sokratyczny, tłum. M. Filipczuk, Warszawa 2018.

Pacewicz A., Hedone. Koncepcja przyjemności w filozofii Platona, Wrocław 2016.

Plato, Philebus, w: Platonis Opera, vol. 2, ed. J. Burnet, Oxford 1910.

Plato, Protagoras, w: Platonis Opera, vol. 3, ed. J. Burnet, Oxford 1909.

Plato, Respublica, w: Platonis Opera, vol. 4, ed. J. Burnet, Oxford 1905.

Plato, Theaetetus, w: Platonis Opera, vol. 1, ed. J. Burnet, Oxford 1905.

Sullivan J. P., The Hedonism in Plato's „Protagoras”, „Phronesis” 6 (1961) No. 1, s. 10-28. Zeyl D. J., Socrates and Hedonism: „Protagoras” 351b-358d, „Phronesis” 25 (1980) No. 3, s. $250-269$. 


\section{Abstrakt}

\section{Przyjemność i dobro w dialogu Protagoras Platona}

Artykuł jest próbą wyjaśnienia, dlaczego w dialogu Protagoras Platon ustami Sokratesa uznaje przyjemność (hedone) za dobro (agathon). Interpretatorzy nie są zgodni co do oceny samej tezy i jej uzasadnienia przez Sokratesa. Wydaje się być ona sprzeczna z poglądami Platona w innych dialogach. Część interpretatorów twierdzi, że jest to prawdziwe spojrzenie samego Sokratesa lub wczesnego Platona z okresu, kiedy pisał dialog. Inni twierdzą, że teza ta jest przesłanką służącą do udowodnienia twierdzenia, iż cnota jest wiedzą. Pojawił się również pogląd, że jedynie pobieżne czytanie tekstu może skłaniać czytelnika do uznania, iż Sokrates poważnie traktuje tezę o związku przyjemności z dobrem. Jeżeli jednak nie traktuje tej tezy poważnie, to dlaczego próbuje przekonać do niej swoich rozmówców? Mając na uwadze te wątpliwości, podjęto analizę tekstu dialogu w celu rozpoznania, czy pojawia się w nim wzmianka o cechach właściwych dobru, które decydują o przyjemności. Ważnym punktem w uzasadnianiu związku przyjemności z dobrem jest wskazanie przez Sokratesa, czym należy się kierować w postępowaniu, aby odczuwać przyjemność w całym życiu i uniknąć złudzeń, dzięki którym pojawia się mniemanie, że przyjemność jest zła. W wyniku przeprowadzonych analiz można postawić wniosek, że decydującą rolę w uzyskaniu stanu gwarantującego przyjemność w całym życiu odgrywa panowanie nad sobą samym.

\section{Słowa kluczowe}

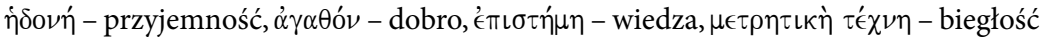
mierzenia, $\sigma \omega \tau \eta \rho^{\prime} \alpha$ - ocalenie, zachowanie

\section{Abstract \\ Pleasure and good in Plato's Protagoras}

The article attempts to explain why Plato in his Protagoras promotes the idea - expressed in this dialogue by Socrates - that pleasure (hedone) is good (agathon). The scholars are not unanimous in their assessment of the thesis and its justification by Socrates. Furthermore, it seems to be in conflict with what Plato expresses in other dialogues. Some commentators maintain that it is the actual view of Socrates or of Plato from the 
time when the dialogue was written. Other say that this thesis is actually the premise for another thesis, namely that virtue is knowledge. An opinion was also voiced that only a cursory reading of Protagoras might lead one to the opinion that Socrates treats the relationship between pleasure and good seriously. However, if he doesn't, then why does he attempt to convince his interlocutors to believe it? Taking all that into concern, an attempt was made to analyze the text in order to determine whether specific characteristics of good that lead to its relationship with pleasure are mentioned there. An important point in Socrates' justification of that relationship is his explanation of what should direct one's actions if one want to feel pleasure throughout one's life and to avoid illusions that might lead to the belief that pleasure is bad. Such analyses lead to the conclusion that self-control plays the key role in achieving the state of pleasure throughout the whole of one's life.

\section{Keywords}

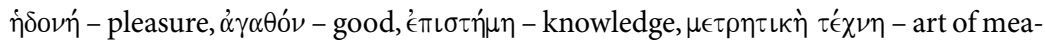
suring, $\sigma \omega \tau \eta \rho i ́ \alpha$ - preservation 